\title{
Genotyping study of Fasciola gigantica isolated from cattle in Aqrah city, Iraq
}

\author{
R.N. Hamoo ${ }^{1 *}$, F.S. Al-Rubaye ${ }^{1}$ and N.G. Mustafa ${ }^{2}$ \\ ${ }^{1}$ Department of Biology, College of Education for Girls, ${ }^{2}$ Department of Physiology, Biochemistry and Pharmacology, \\ College of Veterinary Medicine, University of Mosul, Mosul, Iraq, ${ }^{*}$ Email: rheedhahamoo@yahoo.com
}

(Received April 7, 2019; Accepted May 19, 2019)

\begin{abstract}
This study was conducted to investigate the 18S rRNA gene of Fasciola gigantica obtained from the liver of cattle live in Aqrah city, Iraq. Fifty-nine Fasciola flukes were collected through routine investigation from livers of naturally infected local cattle (42 cows), from May to August 2017, at the central slaughterhouse of Aqrah city, Kurdistan region of Iraq, the flukes were washed by PBS and then fixed in ethanol. Genomic DNA was extracted, and a 560 bp fragment was amplified by PCR, subsequent by sequencing of PCR products. A remarkable result of this project was the deposition of our gene isolate in GenBank (Accession No. MG786553). However, it was confirmed by the sequence results that isolate species was $F$. gigantica, and interestingly our samples sequences have alignment match of $100 \%$ with many international isolates, without genetic mutations or variations. It is concluded that molecular study could be utilized for both diagnosis and differential diagnosis of parasites with huge precise. Also, an $18 \mathrm{~S}$ rRNA gene is a perfect fragment for molecular study and phylogenetic analysis of $F$. gigantica, also our samples have $100 \%$ alignment match with universal isolates.
\end{abstract}

Keywords: 18S rRNA gene, Fasciola gigantica, Iraqi cattle, Phylogenetic tree, Sequencing Available online at http://www.vetmedmosul.com, (C) 2020, College of Veterinary Medicine, University of Mosul. This is an open access article under the CC BY 4.0 license (http://creativecommons.org/licenses/by/4.0/).
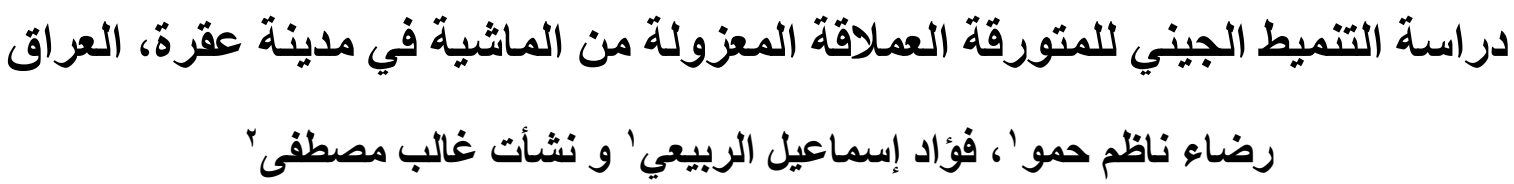

'قسم علوم الحياة، كلية التربية للبنات، ‘فرع الفسلجة والكيمياء الحياتية والأدوية، كلية الطب البيطري، جامعة الموصل، الموصل، العراق

أجريت الدر اسة الحالية للكثف عن جين 18S rRNA المعزولة من طفيل المتورقة العملاقة

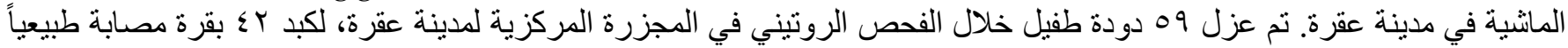

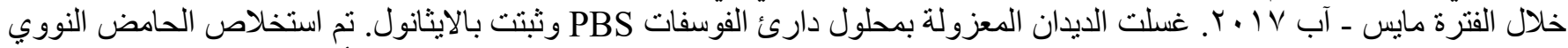

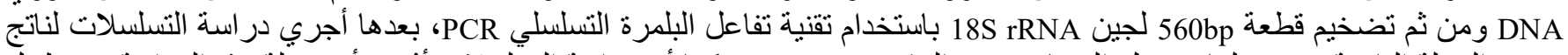
PCR

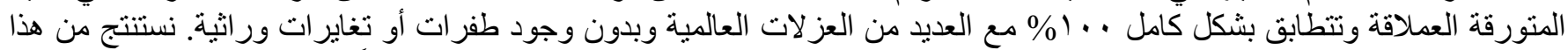

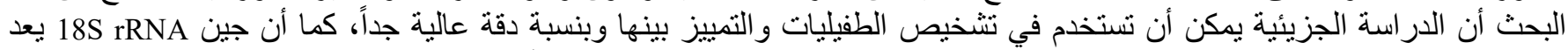
قطعة DNA مناسبة للار اسة الجزيئية وتحليل تطور السئة السلالات لطفيلي المتورقة العملاقة، وأن العينات التي فحصت في هذه الدر اسة كانت منطابقة تماماً مع بعض مض العز لات العالمية. 


\section{Introduction}

A parasitic flatworm $F$. gigantica and/or $F$. hepatica cause fasciolosis, a predominant liver fluke disease of cattle, sheep, and other ruminants. Due to their raised international distribution with high morbidity and mortality, fasciolosis is still money and time consuming vital health topic and directly challenging animal production (1-3). F. gigantica is predominant in many countries of South America, Asia, and Africa, particularly in Iran and Egypt (it was recorded endemic in Nile Delta) (4). Otherwise, Fasciola infects about two million and half of the human population around the world, and many millions are remain in high risk to infection $(5,6)$. Recent and advanced molecular approaches were utilized to the precise study of Fasciola as a parasite. Most commonly used methods were; Random Amplified Polymorphic DNA (RAPD) (7), single nucleotide polymorphism (SNP) (8), PCR-restricted fragment length polymorphism (PCRRFLP) (9), and sequencing of the whole genome (10). The distinction between $F$. hepatica and $F$. gigantica, two common liver flatworms, in the final hosts, particularly in the cattle and sheep, is crucial because of their diverse epidemiological features. Nonetheless, the precise recognition is usually obstinate because of the significant variants in their morphological characteristics. Additionally, more taxonomic complexities in the genus may be due to cross-mating between $F$. hepatica and $F$. gigantica genotypes, giving rise to the new generation forms (11). On the other hand, it has commonly been believed that detailed discrepancy of Fasciola cannot be uniquely attained by morphological inspection (12), and therefore, a comprehensive genetic inquiry is essential (1). Otherwise, $18 \mathrm{~S}$ rRNA gene, as a highly conserved sequence, is one of the most recurrently utilized genes in the studies of Fasciola phylogeny (12).

Therefore, the aim of this study, for the first time in our country, Iraq, was to investigate an $18 \mathrm{~S}$ rRNA gene sequences and their phylogenetic tree of $F$. gigantica taken from the cattle liver, in Aqrah city in Kurdistan region of Iraq.

\section{Materials and methods}

\section{Parasites}

Through routine inspection process between May and August 2017 in the central abattoir of Aqrah city Kurdistan region of Iraq, adult trematode of Fasciola $(\mathrm{n}=59)$ were collected from the naturally infected livers of 42 cattle (both sex). The isolated flukes were looked like $F$. gigantica according to their characteristic morphology, they were washed quietly many periods by using phosphate buffers (PBS), and then fixed with $70 \%(\mathrm{v} / \mathrm{v})$ ethanol and kept at room temperature until extraction of DNA (14).

\section{Extraction of DNA}

Around $10 \mathrm{mg}$ of a side region of adult fluke of Fasciola were cut and pressed by two sterile slides, for some minutes, the ethanol was allowed to vaporize, and the sample was washed for many times by sterile distilled water (13). Depending on the guide of manufacturer, whole genomic DNA was extracted by using QIAGEN DNeasy blood and tissue Kit (CAT No. 69506), then DNA concentration was estimated with NanoDrop ${ }^{\mathrm{TM}}$ 8000 spectrophotometer (ThermoFisher Scientific, USA). A260/280 values greater than 1.8 were considered pure for analysis, and extracted DNA stored at $-20{ }^{\circ} \mathrm{C}$ to $\mathrm{PCR}$ amplification.

\section{PCR and Electrophoresis}

Amplification of 560bp fragment of a $18 \mathrm{~S}$ rRNA gene was employed by the specific primers (Integrated DNA technologies,USA) (F 5'AGTCGTAACAAGGTTTCCGT3' $\mathrm{R}$ 5'GTCCAGCCACAAGGACCG3'). These primers dissolved in the sterile $\mathrm{dH}_{2} \mathrm{O}$ to achieve a stock solution with an ultimate conc. of $100 \mathrm{picomol} / \mu \mathrm{l}$, then stored at -20 to make work primer suspended of $10 \mathrm{pmol} / \mu \mathrm{l} \mathrm{conc}$, after that the stock solution $(10 \mu \mathrm{l})$ was add to the sterile ddH2O $(90 \mu \mathrm{l})$ to attain the last volume $(100 \mu \mathrm{l})$. Reactions of priMix kit of PCR (Taq, 25525 Introns, Korea) involved of PCR priMix $(5 \mu \mathrm{l})[\mathrm{dNTPs}(2.5 \mathrm{mM})$, Taq DNA polymerase $(5 \mathrm{U} / \mu \mathrm{l})$, buffer of reaction $(1 \mathrm{X})(10 \mathrm{X})$, buffer of gel loading $(1 \mathrm{X})], 10 \mathrm{pmols} / \mu 1$ forward primer and $10 \mathrm{pmols} / \mu 1$ reverse primer, $1.5 \mu \mathrm{l}$ of DNA, $16.5 \mu \mathrm{l}$ of sterilized distilled water, and the ultimate PCR reaction volume was $25 \mu$. Thermocycler (Multi-GeneTM Opti-Max Gradient, Labenet, USA) was employed to the mixture amplification, with the next conditions: first denaturation $\left(94^{\circ} \mathrm{C}\right) 5 \mathrm{~min}, 30$ cycles of three phases: 1 . Denaturation $\left(94^{\circ} \mathrm{C}, 30 \mathrm{sec}\right) .2$. Annealing $\left(55^{\circ} \mathrm{C}, 30 \mathrm{sec}\right) .3$. Extension $\left(72^{\circ} \mathrm{C}, 2 \mathrm{~min}\right)$. the final extension $\left(72^{\circ} \mathrm{C}, 10 \mathrm{~min}\right)(7,14)$. Separation of the PCR products was done via $2 \%$ agarose gel electrophoresis (CBS Scientifica, USA), for 90 min., by utilizing of TBE buffer 1x (IBS-BT04, Canda, USA) and ethidium bromide stain. Then considered by introduction of UV wave (302 $\mathrm{nm}$ ) illuminator (Vilbere-lourmate, France), with the using of ladder DNA to recognize the size of bands (Figure 1) (14).

\section{Sequence alignment and phylogenetic analysis}

Five samples of $F$. gigantica that isolated from cattle liver were applied for sequencing by using of $15 \mu 1$ of PCR products, with both primers (forward and reverse). DNA sequencer biotechnology lab machine was applied (3703XIL, Applied-Bio-system) depending on nationals 
instrument centre for environment manage. (NICEM) (www.nicem.snu.ac,kr/main/enskin=index.html). The homolog exploration was performed by BLAST platform that was accessible at NCBI, online at (www.ncbi.nlm.nih.) and Bio-Edit program.

\section{Results}

Fifty-nine Fasciola flukes were collected in the abattoir through routine investigation from livers of naturally infected local cattle, during May-August 2017, at the central slaughterhouse of Aqrah city, Kurdistan region of Iraq. Genomic DNA was extracted successfully, by utilizing specific primers, $560 \mathrm{bp}$ fragment of the $18 \mathrm{~S}$ rRNA gene was amplified (Figure 1), while negative control has no bands on gel electrophoresis. Thus, all collected samples were identified based on the partial nucleotide sequencing of this fragment. A remarkable result of this project was the deposition of our $18 \mathrm{~S}$ rRNA gene isolate in GenBank (Accession No. MG786553). However, it was confirmed by the sequence results that isolate species was $F$. gigantica, and interestingly our samples sequences have alignment match of $100 \%$ with many international isolates, without genetic mutations or variations (Table 1), which achieved by online alignment analysis. Phylogenetic tree analysis (Figures 2 and 3) reveals close similarity $100 \%$ of this article isolates with both Bangladesh and Zambia isolates, and up to $99 \%$ matching with the isolates of other countries; Turkey, Thailand, Egypt, Saudi Arabia, Iran, France, India, and Burkina Faso.

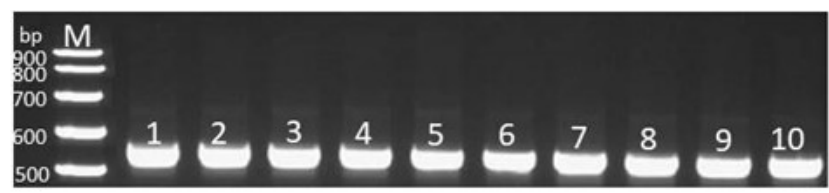

Figure 1. Electrophoresis of PCR product of partial $18 \mathrm{~S}$ rRNA gene, the band size (Lane 1-10 represent samples of F. gigantica) 560 bp. Lane M: DNA ladder (100 bp).

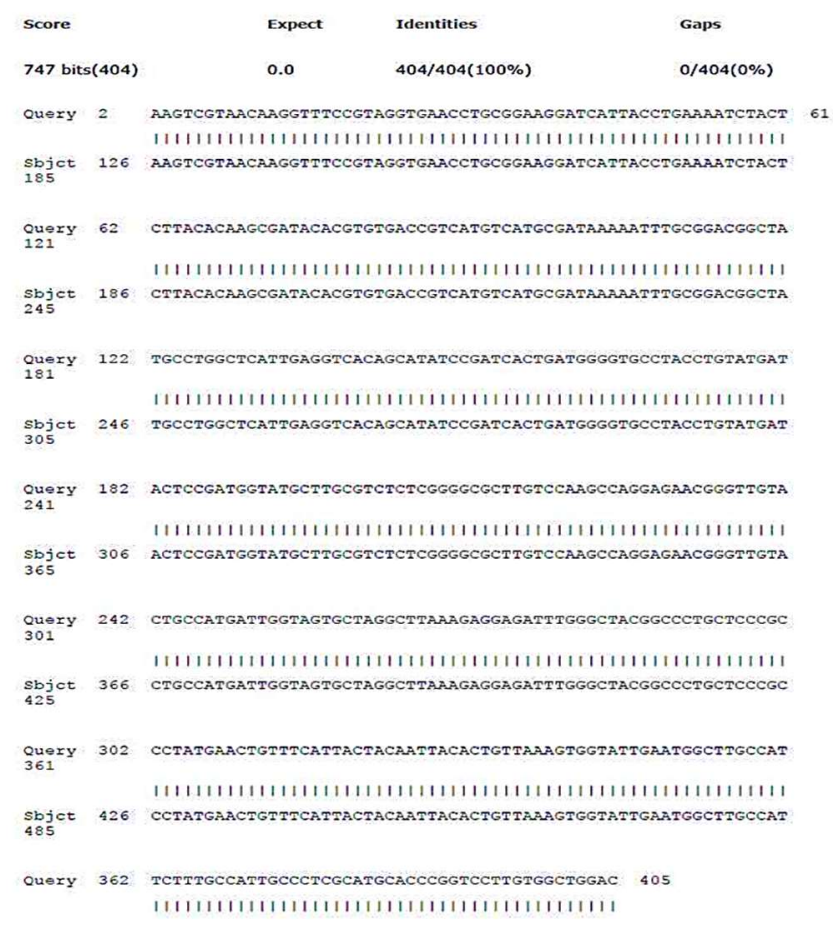

Figure 2: Alignment of the partial sequence of $18 \mathrm{~S}$ rRNA gene of $F$. gigantica sample with the reference.

Table 1: Alignment of $18 \mathrm{~S}$ rRNA gene of Iraqi $F$. gigantica with international accessions. For all isolates; the source is $F$. gigantica, and expect values are 0.0

\begin{tabular}{lcccccc}
\hline Accession & Isolate & Country: city & Gene & Identities & Score & Range \\
\hline ID: MF372919.1 & IR & Iran: Mianeh & 18S rRNA & $100 \%$ & 747 & 126 to 529 \\
ID: KY613943.1 & OMUPAR & Turkey: Samsun & 18S rRNA & $100 \%$ & 747 & 142 to 545 \\
ID: LC076127.1 & 38385 & Egypt & 18S rRNA & $100 \%$ & 747 & 146 to 549 \\
ID: KX198631.1 & 5654456 & India & 18S rRNA & $100 \%$ & 747 & 147 to 550 \\
ID: KM659902.1 & FEg_3a & France & 18S rRNA & $100 \%$ & 747 & 94 to 497 \\
ID: KC476171.1 & BDF-Gt.110 & Bangladesh & 18S rRNA & $100 \%$ & 747 & 113 to 516 \\
ID: HE972274.1 & FgTU1 & Saudi Arabia & 18S rRNA & $100 \%$ & 747 & 137 to 540 \\
ID: AB514853.1 & Thail & Thailand & 18S rRNA & $100 \%$ & 747 & 157 to 560 \\
ID: AB207142.1 & & Zambia: Lusaka & 18S rRNA & $100 \%$ & 747 & 113 to 516 \\
ID: AJ853848.2 & & Burkina Faso: Bobo Dioulasso & 18S rRNA & $100 \%$ & 675 & 1 to 365 \\
\hline
\end{tabular}




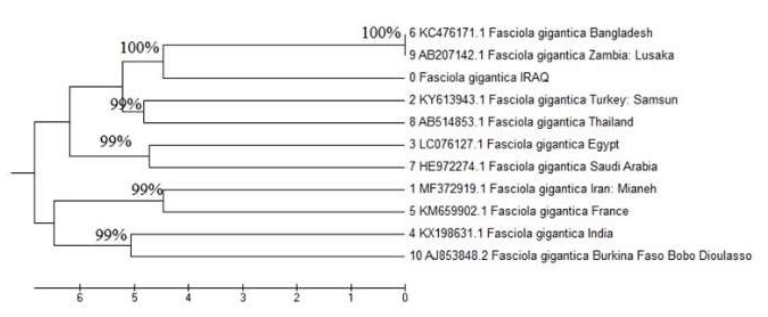

Figure 3: Phylogenetic tree analysis of 18S rRNA gene of Iraqi $F$. gigantica with international accessions.

\section{Discussion}

Various diagnostic approaches were employed to differentiate pathogenic parasites of human and animals, including Fasciola, but at least until now, molecular protocols are the best, the precise, and fully future (15-17). This study, as the knowledge of the authors, is the first in Iraq that utilized an $18 \mathrm{~S}$ rRNA gene of $F$. gigantica in the confirmed diagnosis and differentiation with global isolates which documented in NCBI and GenBank. Also, it should remember that other studies on $F$. gigantica in our country, Iraq was done by the employment of traditional methods as coprology, serology, and copro-antigens, in addition, they applied in the centre and other parts of Iraq, but not in the north (18-21). However, alignment analysis of this study samples reveals $99-100 \%$ matching with global samples deposited on GenBank (Table 1, Figure 2), this result may be referred to the relatively recent introduction of F. gigantica into Iraq. From epidemiological aspects, the existence of the maximum basal fascioloid in African elephants (Proboscides) is suggestive that Africa is the origin of this trematode about 50 million years ago, proboscides spread in Eurasia between 18.5 and 0.8 million years ago. Therefore, authors believed that $F$. gigantica widespread in the Middle East, Asia, and Africa recently (22). As mentioned before, considerably our results are in a good agreement with many authors as Karimi (23), who analysed various regions of the $18 \mathrm{~S}$ rRNA gene (263bp and 356bp) and found that only $0.3 \%$ difference of local Iranian samples when compared with global isolates. In the meantime, Elkhtam and Khalafalla (24) in a genotyping study of goat isolates of $F$. gigantica in Egypt by utilizing an $18 \mathrm{~S}$ rRNA gene with pairwise and multiple alignments reveals high sequence homology, up to $99.9 \%$ matched to the international isolates. On the other hand, sequence alignment and phylogenetic tree analysis (Figure 3 ) reveal complete matching of this study isolates with international records, subsequently, there was no any type of mutations or polymorphisms (as SNPs). This result may be due to that cattle infected mainly by $F$. gigantica only, in contrast to other ruminants, like sheep, which can infected by $F$. hepatica and/or $F$. gigantica, then increasing the possibility of hybridization and cross-mating inside host body, and the following offspring have midway external characters with diverse polidies $(4,5,25)$. The key restraint of this article results is due to $F$. gigantica isolated from the liver of cattle only in Aqrah city in Kurdistan region of Iraq, thus, in the future it must consider various hosts in different regions of the country.

\section{Conclusion}

From the consequence of inquiries, it is possible to conclude that an 18S rRNA gene is an appropriate DNA region for the phylogenetic analysis and molecular investigation of $F$. gigantica.

\section{Acknowledgment}

Authors have great thanks to the University of Mosul and central abattoir of Aqrah city, Iraq, for their nonfinancial support of this article.

\section{References}

1. Yakhchali M, Malekzadeh R, Imani A, Mardani K. Morphological and molecular discrimination of Fasciola species isolated from domestic ruminants of Urmia city, Iran. Iran $\mathrm{J}$ Parasitol. 2015;10(1):46-55.

2. Sah R, Khadka S, Lakhey PJ, Pradhan S, Shah NP, Singh YP, Mas S. Human case of $F$. gigantica-like infection, review of human fascioliasis reports in Nepal, and epidemiological analysis within the South-Central Asia. Acta Parasitol. 2018;63(3):435-443. DOI: 10.1515/ap-2018-0053.

3. Al-Mahmood SS, Al-Sabaawy HB. Fasciolosis: grading the histopathological lesions in naturally infected bovine liver in Mosul city. Iraqi J Vet Med. 2019; 33(2): 379-387. DOI: 10.33899/ijvs.2019.125546.1066.

4. El-Tahawy AS, Bazh EK, Khalafalla RE. Epidemiology of bovine fascioliasis in the Nile Delta region of Egypt: Its prevalence, evaluation of risk factors, and its economic significance. Vet World. 2017;10(10):1241-1249. DOI: 10.14202/vetworld.2017.1241-1249.

5. Vara MP, Villa H, Martinez M, Rojo FA. Genetic heterogeneity of Fasciola hepatica isolates in the northwest of Spain. Parasitol Res. 2007;101(4):1003-1006. DOI: 10.1007/s00436-007-0574-z.

6. Beesley NJ, Caminade C, Charlier J, Flynn RJ, Hodgkinson JE, Martinez A, Martinez M, Perez J, Rinaldi L, Williams DJL. Fasciola and fasciolosis in ruminants in Europe: Identifying research needs. Transbound Emerg Dis. 2017;65:199-216. DOI: 10.1111/tbed.12682.

7. Aryaeipour M, Rouhani S, Bandehpour M, Mirahmadi H, Kazemi B, Rokni MB. Genotyping and phylogenetic analysis of Fasciola spp. isolated from sheep and cattle using PCR-RFLP in Ardabil province, Northwestern Iran. Iranian J Publ Health. 2014;43(10):1364-1371.

8. Cwiklinski K, Dalton JP, Dufresne PJ, La Course J, Williams DJL, Hodgkinson J, Paterson S. The Fasciola hepatica genome: Gene duplication and polymorphism reveals adaptation to the host environment and the capacity for rapid evolution. Genome Biol. 2015;16:71-84. DOI: 10.1186/s13059-015-0632-2.

9. Simsek S, Utuk AE, Balkaya I. Molecular differentiation of Turkey cattle isolates of Fasciola hepatica and F. gigantica. Helminthologia. 2011;48:3-7. doi.org/10.2478/s11687-011-0001-y. 
10. McNulty SN, Tort JF, Rinaldi G, Fischer K, Rosa BA, Smircich P, Fontenla S, Choi YJ, Tyagi R, Hallsworth K, Mann VH, Kammili L, Latham PS, Dell'Oca N, Dominguez F, Carmona C, Fischer PU, Brindley PJ, Mitreva M. Genomes of Fasciola hepatica from the Americas reveal colonization with Neorickettsia endobacteria related to the agents of Potomac horse and human sennetsu fevers. PLoS Genet. 2017;13(1):1006537. DOI: 10.1371/journal.pgen.1006537.

11. Walker SM, Prodohl P, Hoey EM, Fairweather I, Hanna RE, Brennan G, Trudgett A. Substantial genetic divergence between morphologically indistinguishable populations of Fasciola suggests the possibility of cryptic speciation. Int J Parasitol. 2012;42:11931199. DOI: 10.1016/j.ijpara.2012.10.007.

12. Periago MV, Valero MA, El Sayed M, Ashrafi K, El Wakeel A, Mohamed MY, Desquesnes M, Curtale F, Mas S. First phenotypic description of Fasciola hepatica/ F. gigantica intermediate forms from the human endemic area of the Nile Delta, Egypt. Infect Genet Evol. 2008;8:51-8. DOI: 10.1016/j.meegid.2007.10.001

13. Choe SE, Nguyen TT, Kang TG, Kweon CH, Kang SW. Genetic analysis of Fasciola isolates from cattle in Korea based on second internal transcribed spacer (ITS-2) sequence of nuclear ribosomal DNA. Parasitol Res. 2011;109:833-839. DOI: 10.1007/s00436-0112323-6.

14. Ichikawa M, Tokashiki M, Opara MN, Iroh G, Hayashi K, Kumar UM, Itagaki T. Molecular characterization and phylogenetic analysis of F. gigantica from Nigeria. Parasitol Int. 2017;66:893-897. DOI: $10.1016 /$ j.parint.2016.10.010.

15. Martinez JM, Robles D, Rojo FA, Martinez M. Comparison of three different techniques to diagnose Fasciola hepatica infection in experimentally and naturally infected sheep. Vet Parasitol. 2012;190:80-6. DOI: 10.1016/j.vetpar.2012.06.002.

16. Arifin MI, Hoglund J, Novobilsky A. Comparison of molecular and conventional methods for the diagnosis of Fasciola hepatica infection in the field. Vet Parasitol. 2016;232:8-11. DOI: 10.1016/j.vetpar.2016.11.003.

17. Hamoo RN, Mustafa NG, Abdulraheem SA. Nad1 gene analysis of Echinococcus granulosus from sheep in Aqrah city, Iraq. Iraqi J Vet Med. 2019; 33(2): 341-345. DOI: 10.33899/ijvs.2019.162965.

18. Farage HF. Human Fascioliasis in some countries of the Mediterranean Region. East Mediterran Health J. 1998;4:156-160.

19. Al-Mayah SH. Studies on serology, biology, and control of $F$. gigantica Cobbold 1856 infections in Basrah [MSc dissertation]. Basrah: College of Science, University of Basrah, Basrah, Iraq; 2004. $188 \mathrm{p}$.

20. Gzi MH, Rahma JH. Distribution of the parasite $F$. gigantica in the intermediate host in Al-Najaf Al-Ashraf governorate. J Thi-Qar Sci. 2012;3(2):39-47.

21. Shahatha SS. Prevalence of $F$. gigantica among sheep in Al-Anbar governorate and study of effect for aqueous extract of Urtica urens $L$. on the viability of parasite. Anbar J Sci. 2013;7(3):33-38.

22. Raina OK, Jacob SS, Sankar M, Bhattacharya D, Bandyopadyay S, Varghese A, Chamuah JK, Lalrinkima H. Genetic characterization of $F$. gigantica from different geographical regions of India by ribosomal DNA markers. J Parasit Dis. 2015;39(1):2732. DOI: $10.1007 / \mathrm{s} 12639-013-0276-7$

23. Karimi A. Genetic diagnosis of Fasciola species based on $18 \mathrm{~S}$ ribosomal DNA gene. J Biol Sci. 2008;8(7):1166-1173. DOI: $10.3923 /$ jbs.2008.1166.1173.

24. Elkhtam AO, Khalafalla RE. Surveillance of helminthes and molecular phylogeny of $F$. gigantica infecting goats in Sadat district, Egypt. Int J Sci Res Sci Technol. 2016;2(4):188-192.

25. Peng M, Ichinomiya M, Ohtori M, Ichikawa M, Shibahara T, Itagaki T. Molecular characterization of Fasciola hepatica, F. gigantica, and aspermic Fasciola spp. in China based on nuclear and mitochondrial DNA. Parasitol Res. 2009;105:809-815. DOI: 10.1007/s00436-0091459-0. 